[Agr. Biol. Chem., Vol. 31, No. 7, p. 761 766, 1967]

\title{
Studies on Taka-Amylase A under High Pressure
}

\section{Part V Effect of Initial Concentration of Enzyme on the Reactivation of Heat-Inactivated TAA}

\author{
By Kinjiro MiYagawa \\ From the Laboratory of Chemistry, Osaka Joshigakuen College, \\ Tennoji, Osaka \\ Received November 7, 1966
}

\begin{abstract}
Reactivation of heat-inactivated Taka-amylase A (TAA) was dependent on initial concentration of enzyme. The extent of reactivation was greater at higher concentration up to $5.5 \times 10^{-2} \%$ at $\mathrm{pH} 9.0$; above this concentration, reactivation was decreased with increasing of concentration. Spontaneous reactivation became difficult when enzyme was coagulated; however, heat-coagulated enzyme was peptized by pressure $\left(2000 \mathrm{~kg} / \mathrm{cm}^{2}\right)$ and activity could be considerably restored. The higher is the concentration of enzyme, the more the extent of reactivation by compression.
\end{abstract}

\section{INTRODUCTION}

During the course of an investigation of the pressure-inactivation and reactivation of Taka-amylase $\mathrm{A}^{1-4)}$ (Asp. oryzae $\alpha$-amylase, TAA) [EC. 3.2.1.1], it has been found that initial concentration of the enzyme largely affects not only the inactivation but also the reactivation. Although it is well known that protein denaturation is dependent on initial concentration of protein, some of which are more stable and others less stable at higher initial concentration of proteins, little attention has been paid on the initial concentration dependence of renaturation. If the denaturation of protein is reversible, the investigation of the effect of initial concentration of protein on renaturation of denatured protein will present some significant information on the mechanism of denaturation. Even if the protein denaturation is irreversible under

1) K. Miyagawa and K. Suzuki, Arch. Biochem. Biophys., 105, 297 (1964).

2) K. Miyagawa, K. Sannoe and K. Suzuki, ibid., 106, 467 (1964).

3) K. Miyagawa, ibid., 110, 381 (1965).

4) K. Miyagawa, ibid., 113, 641 (1966). atmospheric pressure, moderate pressure may restore the denatured protein depending on circumstances. $^{5 \sim 121}$

In the present paper the effect of initial concentration of the enzyme on reactivation of reversibly heat-inactivated TAA and the effect of moderate pressure on irreversibly heat-inactivated TAA has been studied.

\section{EXPERIMENTAL}

\section{Materials and Procedures}

TAA was prepared from "Taka-diastase Sankyo" according to the method of Akabori et al.13) Aqueous TAA solution was dialyzed against $0.02 \mathrm{M}$ calcium

5) V.S. Tongur and N. A. Kaz'mina, Biokhimiya, 15, $212(1950)$

6) V.S. Tongur and A.M. Tongur, ibid., 16, 410 (1951).

7) V.S. Tongur, Uspekhi Sovremeunor Biol., 31, 391 (1951).

8) V.S. Tongur, Biokhimiya, 17, 495 (1952).

9) V.S. Tongur and V.I. Kasatochin, Khin. i Friz-khin Vyosokomolekul Soedineniyam, 1952, 124.

10) V.S. Tongur and V.I. Kasatochkin, Trudy Vsesoyuz Obshchestva Fiziologov, Biochimikov, i Farmakologov, Akad. Nauk S.S.S.R. 2, 166 (1954).

11) V.S Tongur, Biokhimiya, 19,341 (1954).

12) P. Chahbasi, Thesis, Paris, (1956).

13) S. Akabori, T. Ikenaka and B. Hagihara, J. Biochem., 41, 577 (1954). 
acetate solution and stored as a stock solution (TAA concentration was about $5.5 \%$ ) in a refrigerator. The concentration of TAA was determined spectrophotometrically, assuming the extinction of TAA in water to be $E_{1 \mathrm{~cm}}^{1 \%}=22.1$ at $278.5 \mathrm{~m} \mu$. Unbuffered or buffered solution $(0.05 \mathrm{M}$ tris buffer above $\mathrm{pH} 7.0$, and $0.05 \mathrm{M}$ acetate buffer below $\mathrm{pH} 6.0$ ) of TAA in a test-tube was heated for various period of time and then cooled immediately in ice-water to stop the inactivation. In case of unbuffered solution, samples were diluted twofold with a suitable buffer $(0.1 \mathrm{M}$ acetate buffer or tris buffer) to adjust $\mathrm{pH}$. These heat-treated samples were subjected to moderate pressure treatment for certain period of time. An apparatus and procedures for compression were the same as those in the earlier papers.12) Enzyme activity of the sample was measured with soluble starch as substrate by the method of Noelting and Bernfeld, ${ }^{14}$ ) at the enzyme concentration of $5.5 \times$ $10^{-4} \%$

Sedimentation experiments were conducted at $23^{\circ}$ at 55,430 r.p.m. using a Hitachi Model UCA-1 ultracentrifuge. Ionic strength of the solvent used was kept at 0.1 .

\section{RESULTS}

Reactivation of Heat-inactivated TAA under Atmospheric Pressure

The most favorable $\mathrm{pH}$ range for recovery of heat-treated TAA was determined as follow: unbuffered TAA solution $\left(1.1 \times 10^{-2} \%\right)$ was heated at $99.6^{\circ} \mathrm{C}$ for 5 minutes (activity was completely lost). After cooling, the sample was diluted twofold with buffer solution to adjust to the disired $\mathrm{pH}$ and kept at $30^{\circ} \mathrm{C}$ for various period of time. Extents of reactivation after 4 hours are shown in Fig. 1 (on standing for more than 4 hours, the recovery of activity was constant). Below $\mathrm{pH} 7$, the enzyme activity of TAA was no longer restored, whereas above $\mathrm{pH} 7$, activity was markedly recovered and a maximum recovery was found in the range from $\mathrm{pH} 8$ to 9 . Therefore, the following experiments were carried out at $\mathrm{pH} 9.0$.

The effect of the initial concentration of

14) G. Noelting and P. Bernfeld, Helv. Chim. Acta., 31, 286 (1948).

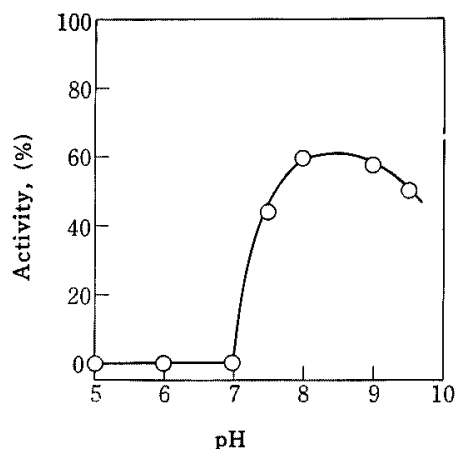

FIG. 1. $\mathrm{pH}$ Dependence of Reactivation of HeatInactivated TAA.

Unbuffered TAA $\left(1.1 \times 10^{-2} \%\right)$ was heated at $99.6^{\circ} \mathrm{C}$ for 5 minutes. After cooling, the sample was diluted twofold with buffer solutions. Activity was measured after 4 hours standing at $30^{\circ} \mathrm{C}$.

the enzyme on the extent of the reactivation of heat-inactivated TAA was studied as follows: TAA solution at various initial concentrations ( $\mathrm{pH} \mathrm{9.0)}$ were heated at $99.6^{\circ} \mathrm{C}$ for 5 and 10 minutes. After 10 minutes heating, TAA above $5.5 \times 10^{-1} \%$ was coagulated. However, below this concentration, and in a whole range of concentration after heating for 5 minutes, solutions were transparent (at $1.1 \%$, solution was very slightly turbid). Enzyme activity was completely lost at every concentration of the enzyme. After cooling, each solution was kept at $30^{\circ} \mathrm{C}$ for 4 hours and activity was measured. As shown in Fig. 2 , the maximum of the remaining activity appears at $5.5 \times 10^{-2} \%$.

Fig. 3 shows the effect of time of heating at $99.6^{\circ} \mathrm{C}$ on the reactivation. TAA solutions of $1.1 \times 10^{-1} \%\left(\mathrm{pH} \mathrm{9.0)}\right.$ were heated at $99.6^{\circ} \mathrm{C}$ over different periods. After cooling, samples were kept at $30^{\circ} \mathrm{C}$ for 4 hours. Reactivation was observed only for those which had been heated for less than 25 minutes.

Effect of Pressure on Reactivation

TAA solutions of 1.1 and $5.5 \times 10^{-2} \%$ at $\mathrm{pH}$ 9.0 were heated at $99.6^{\circ} \mathrm{C}$ for 5 minutes. After cooling, a portion of the samples was 


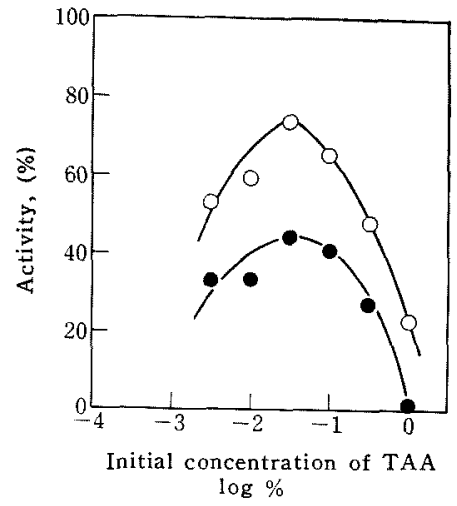

FIG. 2. Dependence of Reactivation on Initial Concentration of TAA.

TAA at various initial concentrations at $\mathrm{pH}$ 9.0 was heated at $99.6^{\circ} \mathrm{C}$ for 5 minutes $(-\mathrm{O}-$ ) and 10 minutes (- - After cooling, activity was measured after 4 hours standing at $30^{\circ} \mathrm{C}$.

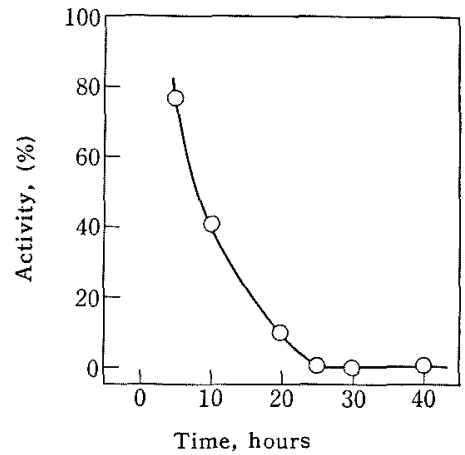

FIG. 3. Effect of Heat Duration on Reactivation.

TAA of $1.1 \times 10^{-1} \%$ at $\mathrm{pH} 9.0$ was heated at $99.6^{\circ} \mathrm{C}$ for various durations. After cooling, activity was measured after 4 hours standing at $30^{\circ} \mathrm{C}$.

kept under atmospheric pressure (control) and the remainder was compressed up to 4000 $\mathrm{kg} / \mathrm{cm}^{2}$ for 2 hours. After release of the pressure, activity was measured for both control and pressure-treated samples at the same time intervals.

As shown in Fig. 4, reactivation was not enhanced during the compression at both concentration examined, and the reactivation was rather depressed by the pressure above

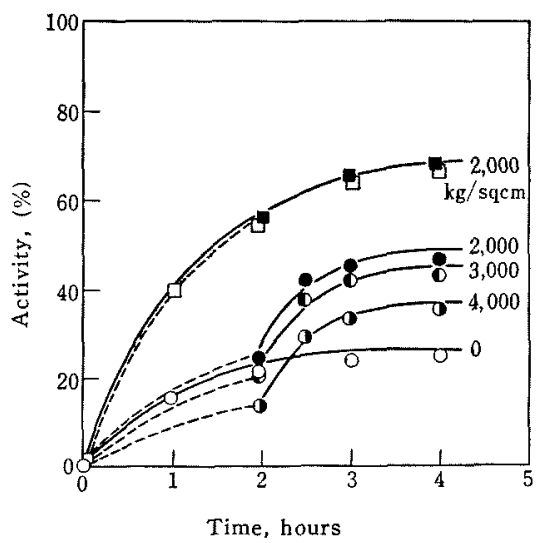

FIG. 4. Effect of Pressure on Reactivation Process.

TAA of $5.5 \times 10^{-2}$ (square) and $1.1 \%$ (circle) at $\mathrm{pH} 9.0$ was heated at $99.6^{\circ} \mathrm{C}$ for 5 minutes. After cooling, samples were compressed for 2

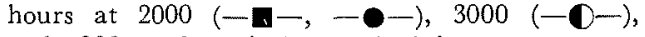
and $4000(-1-) \mathrm{kg} / \mathrm{cm}^{2}$. Activity was measured with time after release of the pressure.

$3000 \mathrm{~kg} / \mathrm{cm}^{2}$ In case of $1.1 \%$ (solution was slightly turbid by heat), after release of the pressure the recovery was increased compared to that of uncompressed TAA, however, at $5.5 \times 10^{-2} \%$ (solution was transparent) no enhancement of recovery was observed even if the pressure was adjusted.

The effect of duration of compression on recovery was studied as follows: TAA of $1.1 \%$ at $\mathrm{pH} 9.0$ was heated at $99.6^{\circ} \mathrm{C}$ for 10 minutes (solution was turbid), and after cooling, a portion of the sample was kept under atmospheric pressure and the remainder was compressed at $2000 \mathrm{~kg} / \mathrm{cm}^{2}$ for different times. Activity was measured at 4 hours after releasing the pressure. As shown in Fig. 5, no recovery of activity was observed for uncompressed sample, but compression caused the partial reactivation, though the prolonged compression more than 20 minutes was not effective to increase the extent of the reactivation.

The effect of initial concentration of TAA on the recovery by pressure was examined as follows: TAA solutions of five different 


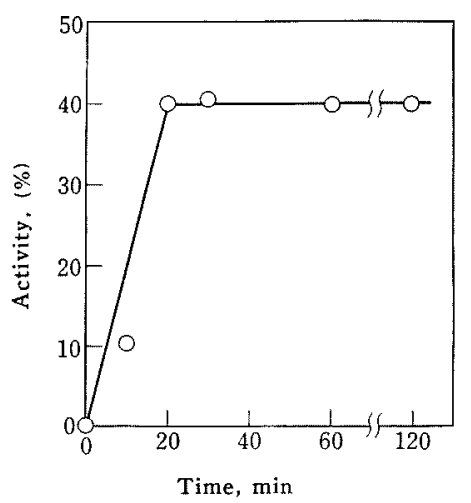

FIG. 5. Effect of Compression Time on Reactivation.

TAA of $1.1 \%$ at $\mathrm{pH} 9.0$ was heated at $99.6^{\circ} \mathrm{C}$ for 10 minutes. After cooling, turbid TAA was compressed at $2000 \mathrm{~kg} / \mathrm{cm}^{2}$ over different periods. Activity was measured after 4 hours standing at $30^{\circ} \mathrm{C}$ after releasing the pressure.

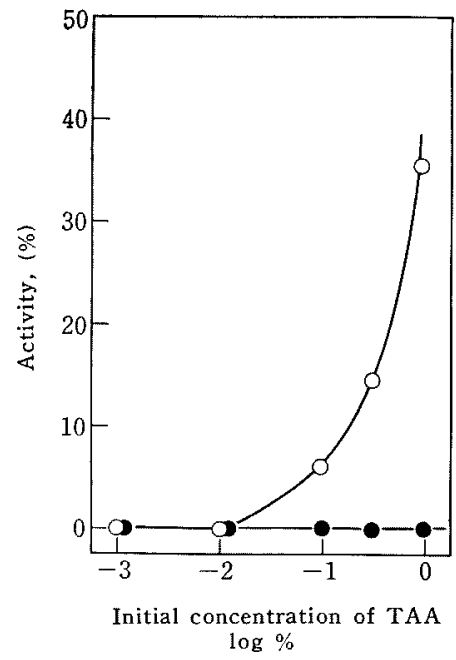

FIG. 6. Effect of Initial Concentration of TAA on Pressure-Reactivation.

TAA at different concentrations was heated at $99.6^{\circ} \mathrm{C}$ for 25 minutes. After cooling, controls were kept under atmospheric pressure (-O-) and portions of samples were compressed at 2000 $\mathrm{kg} / \mathrm{cm}^{2}$ for 20 minutes (- - ). Activity was measured after 4 hours standing at $30^{\circ} \mathrm{C}$.

concentrations at $\mathrm{pH} 9.0$ were heated at $99.6^{\circ} \mathrm{C}$ for 25 minutes (solutions were turbid at concentration of above $10^{-1} \%$, and the degree of turbidity became greater with increasing of concentration). After cooling, a portion of these samples was kept under atmospheric pressure and the remainder was compressed at $2000 \mathrm{~kg} / \mathrm{cm}^{2}$ for 20 minutes. After release of the pressure (turbid solution became clear by compression), samples were kept at $30^{\circ} \mathrm{C}$ and activity was measured after 4 hours. No recovery was observed when the inactivated TAA in each concentrated solution was kept under atmospheric pressure, whereas compression at $2000 \mathrm{~kg} / \mathrm{cm}^{2}$ for 20 minutes brought about considerable reactivation for the concentration above $10^{-1} \%$, and the higher the initial concentration, the more the recovery of activity by compression as shown in Fig. 6 .

In order to clarify the relationship between heat-coagulation and pressure-peptization, TAA (1.196) at $\mathrm{pH} 9.0$ was heated at $99.6^{\circ} \mathrm{C}$ over various period and treated under the pressure of $2000 \mathrm{~kg} / \mathrm{cm}^{2}$ for 20 minutes. Amount of dissolved protein was measured by the Folin method. As illustrated in Table I, coagulation of TAA at $1.1 \%$ was not appreciable for 5 minutes heating, but was complete for 25 minutes heating. For a more concentrated solution (2.75\%) complete coagulation was found even for 5 minutes heating. Coagulated TAA which was heated for less than 25 minutes was apparently peptized by compression, whereas for 40 minutes heating, coagulation became irreversible even if the pressure treatment was made.

Sedimentation experiments were carried out to see the degree of association of TAA samples which were treated by heat and pressure. TAA solutions of $2.25 \times 10^{-1}$ and $1.1 \%$ at $\mathrm{pH} 9.0$ were heated at $99.6^{\circ} \mathrm{C}$ for 10 minutes (TAA in $2.25 \times 10^{-1} \%$ did not become turbid, however, TAA in $1.1 \%$ became white). A part of the samples was kept under atmospheric pressure and the other was treated under $2000 \mathrm{~kg} / \mathrm{cm}^{2}$ for 30 minutes. Sedimentation pattern of heat-denatured TAA at 2.25 $\times 10^{-1} \%$ (Fig. 7-B) shows broad and double peaks, but sedimentation coefficient of main 
Table I. Hheat-Coagulation and Pressure-Dissociation at pH 9.0 (concentration of TAA: $1.1 \%$ )

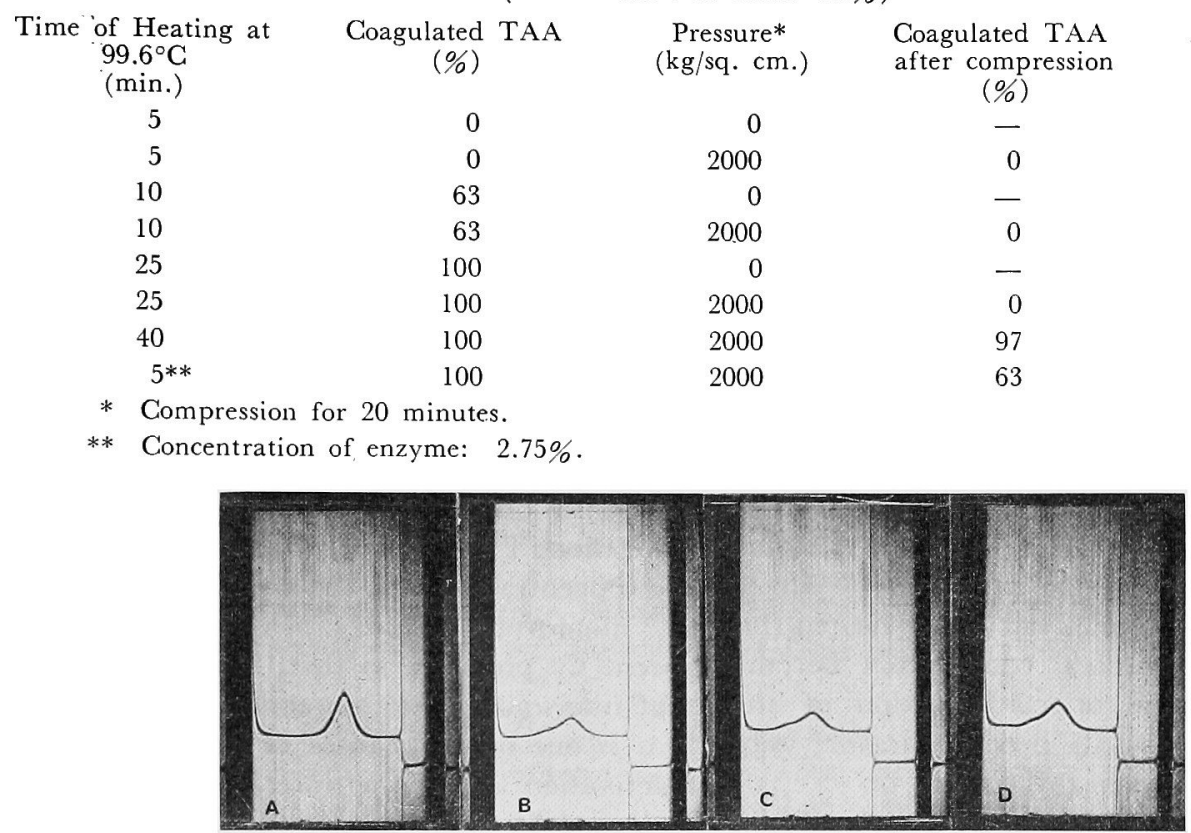

FIG. 7. Sedimentation Diagrams of Native $\left(2.25 \times 10^{-1} \%\right)$ (A), heat-denatured at $99.6^{\circ} \mathrm{C}$ for 10 minutes (B), afterwards, pressure-treated $\left(2000 \mathrm{~kg} / \mathrm{cm}^{2}\right.$ for 30 minutes) (C), and heatcoagulated and pressure-peptized $\left(1.1 \%\right.$ at $99.6^{\circ} \mathrm{C}$ for 10 minutes and $2000 \mathrm{~kg} / \mathrm{cm}^{2}$ for 30 minutes) (D). Photographs were taken at 90 minutes after reaching full speed at 55,430 r.p.m.

Table II. Sedimentation Coefficient $(\mathrm{pH}$ 9.0)

Native TAA*

Heat-denatured TAA*

Heat-denatured and Pressure-treated TAA* Heat-coagulated and Pressure-peptized TAA*

* Concentration of TAA: $2.25 \times 10^{-1} \%$.

** Concentration of TAA: $1.1 \%$.

peak was almost the same as that of native one as illustrated in Table II (heat-denatured TAA at $1.1 \%$ could not be taken because of turbidity). The pattern of heat-denatured $\left(2.25 \times 10^{-1} \%\right)$ and afterwards pressure treated TAA (Fig. 7-C) was very close to that of uncompressed one, and the coagulated and afterwards peptized TAA $(1.1 \%)$ by pressure shows almost same pattern as those of above samples (Fig. 7-D).

\section{DISCUSSION}

The remarkable points of the results obtained in this study are that the recovery of enzyme activity in the heat-inactivated TAA is dependent on the initial concentration of the enzyme and turbid TAA which is not reactivated is peptized and reactivated by pressure $\left(2000 \mathrm{~kg} / \mathrm{cm}^{2}\right)$.

As for heat-inactivation, Nakayama and his co-worker ${ }^{15}$ ) reported that the extents of heatinactivation is decreased with increase in the concentration of TAA, and the phenomenon

15) S. Nakayama and Y. Kono, J. Biochem., 44, 25 (1962). 
was in agreement with the preliminary data of the author. By contrast, the recovery of inactivated TAA was increased with increase of the initial concentration of TAA below $5.5 \times 10^{-2} \%$, and above this concentration the extents of recovery were decreased as shown in Fig. 2. Presumably, change of conformation of the enzyme molecule by heat must be different with different initial concentration of the enzyme and the inactivation and the reactivation should be different with degree of changes of conformation of the enzyme molecules.

As shown in Fig. 3, the reactivation of heat-inactivated TAA is dependent on heatduration, if the enzyme $\left(1.1 \times 10^{-1} \%\right)$ is heated at $99.6^{\circ} \mathrm{C}$ for less than 25 minutes, partial reactivation is possible, but when heated for more than 25 minutes, reactivation become impossible; change of conformation of the enzyme molecule will become drastic with the increase of the heat-duration.

In case of the reactivation of pressure-inactivated TAA, ${ }^{2,3_{1}}$ pressure $\left(1000 \sim 2000 \mathrm{~kg} / \mathrm{cm}^{2}\right)$ enhances the reactivation, however, in case of heat-inactivated TAA, as shown in Fig. 4, at diluted concentration of the enzyme $(5.5 \times$ $\left.10^{-2}, 0^{\prime}\right)$, the recovery of activity was not enhanced by pressure under and after releasing the pressure, however, at $1.1 \%$ reactivation was enhanced after releasing the pressure, though the pressure did not (below $3000 \mathrm{~kg} / \mathrm{cm}^{2}$ ) affect or depress the reactivation above 3000 $\mathrm{kg} / \mathrm{cm}^{2}$ Moreover, as illustrated in Table $\mathrm{I}$, coagulated TAA could be peptized by pressure. It is reasonable to assume that molar volume change of reactivation process of heatdenatured enzyme might be zero or slightly positive, but peptization process of coagulated enzyme might be negative, so that the reactivation can not be enhanced under pressure treatment but if the enzymes were interacted (at higher concentration of the enzyme), pressure can separate the interacted bond and the recovery of activity become possible. However, even if the pressure was applied, highly coagulated enzyme which was heated for a long time or at highly concentrated enzyme, coagulated enzyme could not be peptized (cf. Table I). It is very tempting to suppose that there are at least two kinds of bond which contribute to the coagulation of the enzyme by heat; one is separated but the other can not be by pressure.

As shown in Fig. 6, the extent of the reactivation of heat-inactivated TAA by perssure increased with increase of the initial concentration of the enzyme. At lower concentration, TAA was not turbid but the higher the concentration was, the greater the turbidity, moreover, turbid TAA became transparent by pressure, so that, it seems probable that inter-molecular interaction of enzyme by heat is one of the causes of impossibility of reactivation and if the interacted enzyme is separated by some means (in this case, pressure), the reactivation will become possible.

The broad and double peaks of sedimentation diagram of heat-denatured TAA (sedimentation coefficient of the main peak is almost the same as that of native one) (Fig. 7-B) show that enzyme molecule is largely transformed and some of the molecule are associated by heat. Moreover, patterns and coefficients of pressure-treated samples (Fig. 7-C and D) are almost the same as that of untreated one. This seems to indicate that the pressure can separate the coagulated enzyme but does not affect the reconstruction of denatured molecule.

Acknowledgement. The author wishes to thank Professor Dr. S. Ono, of University of Osaka Prefecture and Professor Dr. K. Suzuki, of Ritumeikan University for their kind guidances and discussions throughout this work. 